\title{
Reliabilitas Prediksi Curah Hujan Dasarian Pada Kejadian Curah Hujan Ekstrim Pemicu Banjir 26 Oktober 2020 di Kebumen: Model Statistik (HyBMG) versus Model Dinamik (ECMWF)
}

\author{
Zauyik Nana Ruslana ${ }^{1 *}$, Restu Tresnawati ${ }^{1}$, Rosyidah $^{1}$, Iis Widya Harmoko ${ }^{1}$ dan Siswanto ${ }^{2}$ \\ ${ }^{1}$ Stasiun Klimatologi Semarang \\ ${ }^{2}$ Pusat Layanan Informasi Iklim Terapan, Badan Meteorologi Klimatologi dan Geofisika, Jakarta
}

\begin{abstract}
Abstrak
Kejadian banjir di Kabupaten Kebumen tanggal 26 Oktober 2020 dipicu oleh hujan dengan intensitas sangat lebat hingga ekstrim yang berlangsung sejak Minggu (25 Oktober 2020) sore hingga Senin (26 Oktober 2020). Beberapa pos pengamatan hujan (kerjasama) menunjukkan curah hujan $>150 \mathrm{~mm} /$ hari (kategori ekstrim) dalam rentang waktu hujan tanggal 24-26 Oktober 2020. Analisis curah hujan kumulatif dasarian ke-III bulan Oktober 2020 di wilayah Kabupaten Kebumen menunjukkan curah hujan $>300 \mathrm{~mm} /$ dasarian (kriteria sangat tinggi). Sebelumnya, pada dasarian ini BMKG Stasiun Klimatologi Semarang memprakirakan sebagian besar wilayah Kabupaten Kebumen diprakirakan dalam kriteria menengah dengan curah hujan berkisar antara 101-150 mm/dasarian. Berdasarkan laporan yang masuk ke BPBD Kebumen sedikitnya 25 desa di 7 kecamatan terendam banjir karena beberapa sungai yang ada di Kebumen meluap. Paper ini bertujuan menguji keandalan prakiraan curah hujan dasarian operasional dengan membandingkan luaran prakiraan dengan data observasi pada kondisi ekstrem tersebut. Uji sensitivitas model univariat HyBMG dan ECMWF dilakukan dengan metode visual kesesuaian spasial, korelasi sederhana dan RMSE. Hasil analisis menunjukkan nilai luaran prakiraan ECMWF memiliki nilai RMSE terkecil namun dengan nilai korelasi yang negatif. Korelasi kuat diperoleh dari metode ANFIS dengan nilai RMSE sebesar 556,5. Dapat disimpulkan bahwa luaran model ANFIS memiliki tingkat sensitivitas luaran prakiraan yang lebih handal untuk kejadian hujan ekstrim pada hari Minggu (25 Oktober 2020) di Kabupaten Kebumen. Metode HyBMG memerlukan penambahan input data series lebih banyak lagi sehingga informasi yang terkumpul lebih banyak dan data grid luaran ECMWF menjadi lebih rapat, diharapkan dapat menghasilkan nilai prediksi yang lebih baik lagi.
\end{abstract}

Kata kunci: ANFIS; ECMWF; ARIMA; HyBMG; RMSE

\section{Abstract}

The flood incident in Kebumen Regency on October 26, 2020 was triggered by rain with very heavy to extreme intensity which lasted from Sunday (25 October 2020) afternoon to Monday (26 October 2020). Several rain observations posts (cooperation) show rainfall $>150 \mathrm{~mm} /$ day (extreme category) in the period of rain from 24-26 October 2020. Analysis of the third basic cumulative rainfall in October 2020 in the Kebumen Regency area shows rainfall $>300 \mathrm{~mm} / 10$ days rainfall (very high criterion). Previously, the BMKG Semarang Climatology Station predicted that most of the Kebumen Regency area was predicted to be in the medium criteria with rainfall ranging from $101-150 \mathrm{~mm} /$ dasarian. Based on reports submitted to the Kebumen $B P B D$, at least 25 villages in seven sub-districts were flooded because several rivers in Kebumen were overflowing. This paper is intended to test the reliability of operational basic rainfall forecasts by comparing the forecast output with observational data in these extreme conditions. Then the sensitivity test of the univariate HyBMG and ECMWF models was carried out using visual methods of spatial suitability, simple correlation and RSME. The results of the analysis show that the ECMWF forecast output value has the smallest RMSE value but with a negative correlation value.

\footnotetext{
*) Korespondensi: aziexzazak@gmail.com

Diajukan : 22 Maret 2021

Diterima : 26 April 2021

Diterbitkan : 31 Juli 2021
} 
A strong correlation was obtained from the ANFIS method with an RMSE value of 556.5. This study concludes that the ANFIS model output has a more reliable level of forecast output sensitivity for extreme rain events on Sunday (25 October 2020) in Kebumen Regency. The HyBMG method requires adding more input data series so that more information is collected and the data from the ECMWF output grid is tighter, which is expected to produce better predictive values.

Keywords: ANFIS; ECMWF; ARIMA; HyBMG; RMSE

\section{PENDAHULUAN}

Hujan deras yang mengguyur Kabupaten Kebumen sejak Minggu (25 Oktober 2020) sore hingga Senin (26 Oktober 2020) pagi mengakibatkan banjir dan tanah longsor. Berdasarkan laporan yang masuk ke BPBD Kebumen sedikitnya 25 desa di 7 kecamatan terendam banjir karena beberapa sungai yang ada di Kebumen meluap (Heksantoro, 2020). Satu tahun sebelumnya di Kabupaten Kebumen juga dilanda banjir yang disebabkan juga oleh tingginya curah hujan yang terjadi di wilayah Kebumen pada 15-16 Januari 2019. Disampaikan Plt Kalak BPBD Kebumen Teguh Kristiyanto, hingga Selasa siang terdapat 40 desa di 10 kecamatan yang terdampak tingginya curah hujan. Dari jumlah itu, data pada Pusat Kendali dan Operasi (Pusdalops) BPBD Kebumen terdapat sedikitnya 70 titik bencana, baik banjir maupun tanah longsor.

Dari data historis kejadian banjir di Kabupaten Kebumen (BNPB, 2021) dalam 5 tahun terakhir antara 2015 hingga 2019 telah terjadi sebanyak 13 kali kejadian banjir dan 2 kali terjadi pada bulan Oktober yaitu tahun 2016 dan 2017. Kabupaten Kebumen secara administratif terdiri dari 26 kecamatan dengan luas wilayah sebesar $158.111,50$ hektar atau $1.581,115 \mathrm{~km}^{2}$, dengan kondisi beberapa wilayah merupakan daerah pantai dan pegunungan, tetapi sebagian besar merupakan dataran rendah, dengan letak wilayah pada $7^{0}$ $27^{\prime}-7^{0} 50^{\prime}$ LS dan $109^{0} 33^{\prime}-109^{0} 50^{\prime}$ BT (PUSDATARU JATENG, 2018).

Stasiun Klimatologi Semarang memiliki tugas dan fungsi untuk menyediakan layanan analisis dan prakiraan curah hujan di seluruh Jawa Tengah. Kegiatan operasional rutin pembuatan prakiraan curah hujan dasarian maupun bulanan di Stasiun Klimatologi Semarang memanfaatkan dua model prakiraan yaitu model berbasis statistik dan berbasis model dinamik.

Paper ini bertujuan untuk menguji keandalan prakiraan curah hujan dasarian operasional dengan membandingkan luaran prakiraan dengan data observasi untuk kejadian curah hujan ekstrem serta melakukan pengujian sensitivitas diantara model yang dijalankan operasional model mana yang menunjukkan keandalan luaran prakiraan untuk kondisi ekstrim tersebut.

\section{METODOLOGI}

Model statistik yang digunakan meliputi model HyBMG, sedangkan model dinamis adalah luaran dari model ECMWF. HyBMG merupakan aplikasi model prediksi berbasis statistik yang dikembangkan oleh Puslitbang BMKG yang dapat digunakan untuk melakukan prediksi iklim dalam skala waktu dasarian maupun bulanan. Modul prediksi statistik menggunakan metode univariat yang tersedia dalam aplikasi HyBMG adalah ARIMA, ANFIS, Wavelet ANFIS dan Wavelet ARIMA. Prakiraan curah hujan dasarian secara operasional BMKG Stasiun Klimatologi Semarang adalah rerata ensmbel dari beberapa luaran perhitungan model statistik (HyBMG) dan dinamik (ECMWF).

Dalam kegiatan operasional, selain luaran prediksi model statistik oleh aplikasi HyBMG, prakiraan iklim dasarian dan bulanan di Stasiun Klimatologi Semarang juga menggunakan luaran model dinamis ECMWF. ECMWF merupakan pusat layanan prediksi iklim internasional yang menyediakan luaran model prediksi atmosfer/cuaca global jangka menengah (10 harian) maupun jangka panjang (musim). Dalam praktiknya, luaran model prakiraan ECMWF lebih banyak berperan dalam kesimpulan dan justifikasi prakiraan operasional dasarian dan bulanan karena sudah mempertimbangkan faktor dinamis dari sirkulasi atmosfer dan suhu permukaan laut, termasuk di dalamnya variabilitas iklim La Nina/El Nino. Hasil luaran prakiraan operasional inilah yang akan didiseminasikan dalam bentuk buletin format digital dan cetak kepada stakeholder terkait dan menjadi informasi publik yang disiarkan melalui berbagai media.

Gambar 1 mendeskripsikan sebaran daerah yang terendam banjir di 25 desa di 7 kecamatan di wilayah Kabupaten Kebumen berdasarkan rekap 


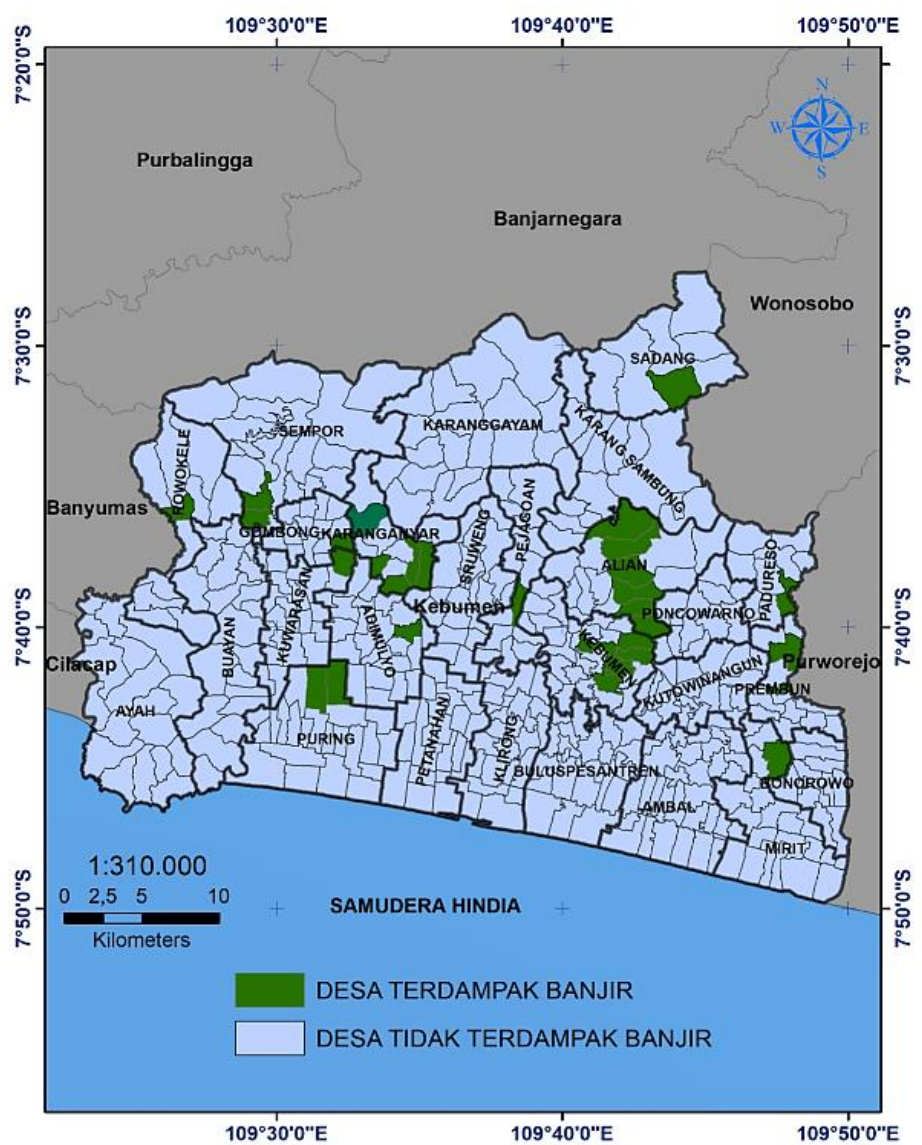

Gambar 1. Peta wilayah terdampak banjir pada tanggal 26 Oktober 2020 yang terdiri dari 25 desa di 7 kecamatan di Kabupaten Kebumen

data bencana dari BPBD Provinsi Jawa Tengah. Untuk mengkaji curah hujan pemicu banjir di wilayah tersebut, digunakan 13 titik pos hujan dalam membuat analisis dan prakiraan curah hujan untuk setiap wilayah ZOM (Zona Musim) di Kabupaten Kebumen dan sekitarnya. Data pos hujan yang memenuhi kriteria lengkap dan digunakan yaitu Pos Hujan Wanareja (ZOM 98), BPP Kesugihan dan Stasiun Meteorologi Cilacap (ZOM 99), Banyumas PU dan Kedung Waringin (ZOM 102), Karang Kemiri SMPK, Purwonegoro dan Wanadadi (ZOM 112), Penusupan (ZOM 113), Bedakah (ZOM 114), Gombong (ZOM 115), Kaliloro dan Salaman (ZOM 120). Selain itu, untuk menggambarkan sebaran spasial curah hujan pada saat kejadian, digunakan pula data estimasi curah hujan produk citra satelit GSMAP yang diunduh dari laman JAXA melalui cara file transfer protocol (rainmap@hokusai.eorc.jaxa.jp/realtime/daily0.1/0 0Z-23Z). Estimasi curah hujan Satelit GSMaP merupakan produk pemetaan curah hujan resolusi tinggi dan cukup presisi di seluruh bagian dunia yang dikelola oleh JAXA
Precipitation Measuring Mission (PMM) dari tahun 2007 sampai sekarang. Sebelumnya program ini disponsori oleh Core Research for Evolutional Science and Technology (CREST) pada Japan Science and Technology Agency (JST) dari tahun 2002 2007. GsMAP merupakan penggabungan data dari beberapa satelit cuaca seperti TRMM, Aqua, Adeos II, DSMP dan NOAA (Susila dkk., 2017).

Analisa dan uji sensitivitas dengan pendekatan model statistik dan dinamis dilakukan dengan 3 (tiga) tahapan sebagaimana digambarkan pada diagram Gambar 2, yaitu meliputi:

Tahap 1. Prediksi curah hujan dasarian menggunakan aplikasi $H y B M G$

Pada tahap ini data curah hujan dari beberapa pos hujan di Kabupaten Kebumen dan sekitarnya dipilih dan diverifikasi dengan data yang lengkap tidak ada yang hilang atau kosong. Penyusunan data dasarian dalam satu series kebawah format .txt selama 10 tahun terakhir yaitu dari dasarian ke-30 tahun 2010 sampai dengan dasarian ke-29 tahun 2020. 


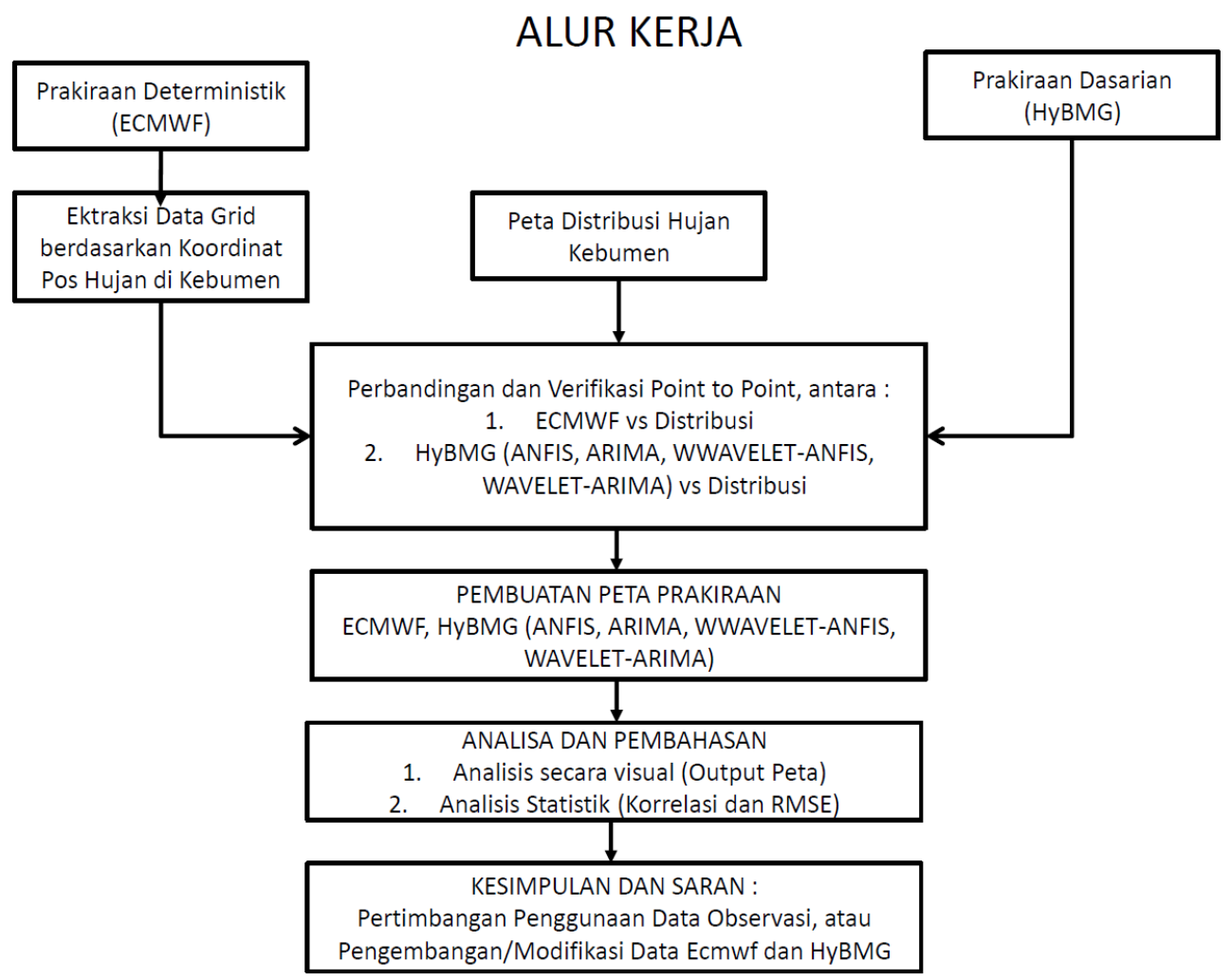

Gambar 2. Alur kerja/flowchart dalam pengolahan output prakiraan dari ECMWF dan HyBMG dan membandingkan dengan hasil observasi di Kabupaten Kebumen. Perbandingan dari masing-masing luaran prakiraan ensemble mean ECMWF dan dari HyBMG (Ensembel Mean, ARIMA, ANFIS, Wavelet-ANFIS, Wavelet-ARIMA) dengan hasil pengumpulan data dari titik pos hujan observasi pada masing-masing ZOM di wilayah Kabupaten Kebumen dan sekitarnya.

Selanjutnya dilakukan proses running prediksi univariat menggunakan aplikasi HyBMG yang merupakan salah satu model yang dikembangkan oleh Puslitbang BMKG dengan basis waktu prediksi dasarian maupun bulanan. Modul prediksi metode univariat yang tersedia dalam aplikasi HyBMG meliputi model ARIMA, ANFIS, Wavelet-ANFIS dan Wavelet-ARIMA.

ARIMA (Autoregressive Integrated Moving Average) merupakan salah satu teknik peramalan dengan pendekatan deret waktu yang menggunakan teknik- teknik korelasi antar suatu deret waktu. Model ARIMA merupakan model yang berbasis korelasi (dependen) secara statis antar deret pengamatan, yaitu pengamatan sekarang $(z t)$ tergantung pada satu atau beberapa pengamatan sebelumnya $(z t-k)$. Adanya dependensi antar pengamatan diketahui dari uji korelasi antar pengamatan yang sering dikenal dengan fungsi autokorelasi (autocorrelation function/ACF) (Iriawan dan Astuti, 2006). Model Adaptive Network-Based Fuzzy Inference System (ANFIS) adalah model fuzzy logic yang menerapkan konsep jaringan adaptive (Jang, J.S.R, 1993). Pada model ini, neural-network akan mengenali pola-pola dan menyesuaikan pola terhadap perubahan yang ada, sedangkan fuzzy logic menggabungkan pengetahuan manusia dan mencari kesimpulan untuk membuat suatu keputusan (Komalasari dkk., 2016). Model Wavelet berbasis small wave atau gelombang singkat yang memberikan informasi frekuensi yang muncul juga dan informasi tentang skala atau durasi atau waktu yang dihasilkan dari Transformasi Wavelet. Wavelet dapat digunakan untuk menganalisis suatu bentuk gelombang (sinyal) sebagai kombinasi dari waktu (skala) dan frekuensi. (Putra, 2010). Dari semua luaran modul HyBMG dari model-model tersebut kemudian dirata-ratakan untuk mendapatkan Ensemble Mean.

Tahap 2. Prediksi curah hujan dasarian dengan ECMWF

Luaran prediksi curah hujan juga dapat diperoleh dari ECMWF (European Centre for Medium- 
Range Weather Forecasts). ECMWF merupakan organisasi internasional yang menyediakan data prediksi atmosfer/cuaca global jangka menengah (10 harian) maupun jangka panjang (bulan hingga musim) (ECMWF, 2016). ECMWF merupakan lembaga atau pusat prediksi cuaca dan iklim konsorsium dari 31 negara di benua Eropa yang juga didukung oleh World Meteorological Organization (WMO), European Space Agency (ESA), dan organisasi lainnya (Subakti, 2012). Sejak 10 tahun terakhir, BMKG telah menggunakan produk luaran ECMWF untuk memprediksi musim dan iklim secara umum di Indonesia. Luaran prediksi curah hujan ECMWF berupa format .mat, yang kemudian diekstrak dalam format .xlxs dengan aplikasi AII-Tools BMKG dan di downscale hingga dihasilkan output data 51 ensemble dan rata-rata prediksi curah hujan pada pos hujan di wilayah Kabupaten Kebumen dan sekitarnya.

Tahap 3. Pengujian Korelasi dan RMSE

Pengujian korelasi dalam penelitian ini digunakan untuk menganalisis hubungan secara kuantitatif antara semua hasil luaran model prediksi dengan verifikasi hasil observasi. Seberapa besar kesesuaian antara dua variabel tersebut dinyatakan dalam sebuah koefisien korelasi. Semakin besar koefisien korelasi maka semakin besar kesesuaian antara yang diprakirakan dengan keadaan senyatanya dari observasi. Terdapat pedoman untuk memberikan interpretasi koefisien korelasi menurut Sugiyono (2012;257) yang ditunjukkan pada Tabel 1.

Nilai koefisien korelasi berkisar antara -1 dan 1. Tanda positif atau negatif menunjukkan arah korelasinya. Bila korelasi antara $\mathrm{x}$ dan $\mathrm{y}$ negatif maka kenaikan variabel $\mathrm{x}$ akan menyebabkan penurunan y atau sebaliknya. Bila korelasi antara $\mathrm{x}$ dan y positif maka kenaikan variabel $\mathrm{x}$ akan diikuti dengan kenaikan variabel $y$ atau sebaliknya. Korelasi ditentukan berdasarkan tingkat kepercayaan (Apriyana dan Kailaku, 2015). Koefisien korelasi dapat menunjukkan kekuatan dan arah dari korelasi, seperti yang ditunjukkan pada spektrum di Gambar 3.

Nilai RMSE digunakan untuk mengetahui besarnya penyimpangan yang terjadi antara nilai prediksi total curah hujan bulanan dibandingkan dengan nilai total curah hujan bulanan aktual hasil observasi. Persamaan 1 digunakan untuk menghitung RMSE yang digunakan dalam pengolahan data

$$
R M S E=\sqrt{\frac{\sum_{i=1}^{n}(R C i-R O i)^{2}}{N}}
$$

Dimana: $\mathrm{N}=$ Banyaknya data, $\mathrm{RCi}=$ Curah hujan hasil estimasi ke-i (mm), dan ROi $=$ Curah hujan aktual hasil observasi ke-i (mm).

RMSE merupakan standar deviasi dari residual (error prediksi). Residual menggambarkan ukuran sebaran data terhadap garis regresinya, sedangkan RMSE adalah ukuran dari sebaran residual. Dengan kata lain, RMSE menunjukkan konsentrasi data yang paling mendekati di sekitar garis liniernya. Uji RMSE umumnya digunakan dalam klimatologi, peramalan dan analisis regresi untuk verifikasi hasil eksperimen (Swarinoto dan Sugiyono, 2011).

Tabel 1. Interpretasi koefisien korelasi

\begin{tabular}{ll}
\hline Nilai Korelasi & Interpretasi \\
\hline $0.00-0.199$ & Korelasi sangat rendah \\
$0.20-0.399$ & Korelasi Rendah \\
$0.40-0.599$ & Korelasi Sedang \\
$0.60-0.799$ & Korelasi Kuat \\
$0.80-1.000$ & Korelasi Sangat Kuat \\
\hline
\end{tabular}

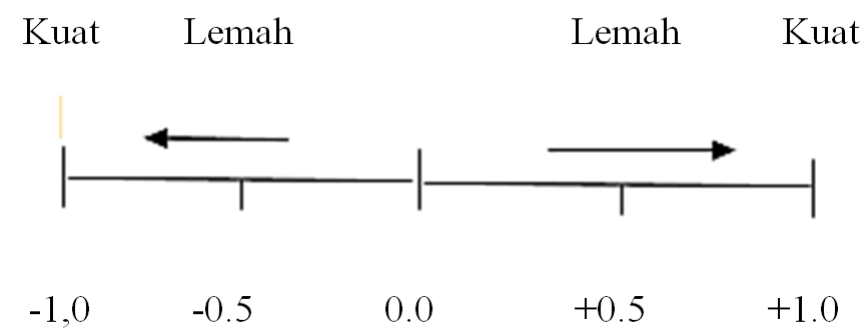

Gambar 3. Spektrum Koefisien Korelasi (Gogtay dan Thatte, 2017). 
Perhitungan nilai RMSE dapat juga digunakan rumusan-rumusan sebagai berikut:

Dimana:

$$
R M S E=\sqrt{(f-o)^{2}}
$$

$$
\begin{aligned}
& \mathrm{f}=\text { hasil prediksi } \\
& \mathrm{o}=\text { nilai observasi }
\end{aligned}
$$

$$
\begin{aligned}
& \text { RMSE }=\left[\begin{array}{ll}
\left(\sum_{I=1}^{N}\right. & \left(z_{f_{i}}-z_{o_{i}}\right)^{2} / N
\end{array}\right]^{1 / 2} \\
& \text { Dimana : } \\
& \begin{array}{l}
\Sigma=\text { penjumlahan } \\
\text { (zfi }- \text { Zoi) Sup }>2=
\end{array} \\
& \begin{array}{l}
\text { kuadrat selisih data } \\
\text { observasi dengan } \\
\text { prediksinya }
\end{array} \\
& \mathrm{N}=\text { ukuran sampel }
\end{aligned}
$$

Dalam rumusan RMSE seperti pada persamaan (1) sampai (4) diatas akan didapat gambaran bagaimana data hasil prediksi terkonsentrasi di sekitar nilai observasinya. Dalam ilmu data, RMSE memiliki beberapa tujuan, antara lain :

1. Berfungsi sebagai proses dalam model training/pelatihan

2. Mengevaluasi model terlatih sebagai kegunaan akurasi (Mardianto dkk., 2021)

\section{HASIL}

\section{Analisa Hujan Harian Kebumen}

Peta analisis spasial distribusi curah hujan hasil interpolasi dari data observasi dan distribusi spasial estimasi curah hujan dari citra GSMaP (Global Satellite Mapping of Precipitation) selama 3 hari berturut-turut yang berkaitan dengan kejadian banjir pada 26 Oktober 2020 di Kabupaten Kebumen disajikan dalam Gambar 4. Kejadian banjir dapat dikaitkan dengan curah hujan sangat tinggi (100-150 mm/hari) hingga level ekstrim $(>150 \mathrm{~mm} /$ hari) yang suda turun sejak 24 Oktober 2020 yang terdistribusi di beberapa wilayah kecamatan di Kabupaten Kebumen.

Pada tanggal 24 Oktober 2020 (pencatatan tanggal 25 Oktober 2020 pukul 07.00 WIB), diketahui curah hujan ekstrim terdiistribusi di Kecamatan Buluspesantren dan sebagian Kecamatan Klirong dan Kebumen, serta sebagian kecil Kecamatan Ambal dan Sruweng (Gambar 4(a)). Sementara tanggal 25 Oktober 2020 (pencatatan tanggal 26 Oktober 2020 Pukul 07.00 WIB) curah hujan ekstrim melanda wilayah sebagian besar Kecamatan Karanggayam, sebagian wilayah Kecamatan Rowokele, Sempor, Karangsembung dan sadang, sebagian kecil wilayah Kecamatan Karanganyar dan Pejagoan (Gambar 4(c)). Untuk tanggal 26 Oktober 2020 (pencatatan tanggal 27 Oktober 2020 pukul 07.00 WIB) meliputi wilayah sebagian wilayah Kecamatan Rowokele, Karanggayam, Karanganyar, Sruweng dan Pejagoan, sebagian kecil wilayah Kecamatan Gombong, Adimulyo, Kebumen, Alian, Sadang dan Karangsambung (Gambar 4(e)).

Secara umum, curah hujan ekstrim harian pada dasarian ini terkonsentrasi di bagian tenggara, utara dan tengah wilayah Kabupaten Kebumen. Distribusi curah hujan yang dihasilkan oleh pengolahan data hasil observasi pos hujan tersebut rupanya tidak sama dengan hasil pengolahan data citra satelit GSMaP. Pada tanggal 24 Oktober 2020, estimasi curah hujan GSMAP berkisar antara $0.5-20 \mathrm{~mm} /$ hari (kategori hujan ringan) untuk sebagian wilayah Kabupaten Kebumen (gambar 4(b)). Sedangkan untuk tanggal 25 Oktober 2020 (gambar 4(d)) estimasi curah hujan di sebagian besar wilayah berkisar antara $20-50 \mathrm{~mm} /$ hari (kategori hujan sedang) dengan spot hujan lebat meliputi sebagian wilayah Kecamatan Sempor, Karanggayam dan Ayah, hal yang berbeda dengan kolokasi hasil observasi. Estimasi curah hujan tanggal 26 Oktober 2020 (gambar 4(f)) berkisar antara $0.5-20 \mathrm{~mm} /$ hari (kategori hujan ringan), yang berbeda jauh dengan hasil observasi dimana pada tanggal tersebut merupakan hari dengan curah hujan sangat lebat hingga ekstrim yang terdistribusi cukup merata.

Perbandingan dengan analisis data observasi tersebut menunjukkan bahwa estimasi citra GSMaP cenderung underestimate dalam menggambarkan intensitas curah hujan yang sebenarnya sesuai hasil observasi permukaan, serta belum mampu mendeteksi curah hujan ekstrim pemicu kejadian banjir, meskipun variasi spasial curah hujan kategori ringan hingga sangat lebat dapat dikenali sebaran atau polanya. Hal ini menjadi catatan bagi kegiatan operasional Stasiun Klimatologi Semarang bahwa pemanfaatan data satelit hujan belum dapat digunakan secara presisi untuk mendeteksi curah hujan ekstrim yang dapat memicu banjir, meskipun pola sebaran spasialnya tetap dapat dimanfaatkan sebagai panduan, terutama untuk kasus curah hujan ekstrim pemicu banjir di Kabupaten Kebumen Oktober 2020. 


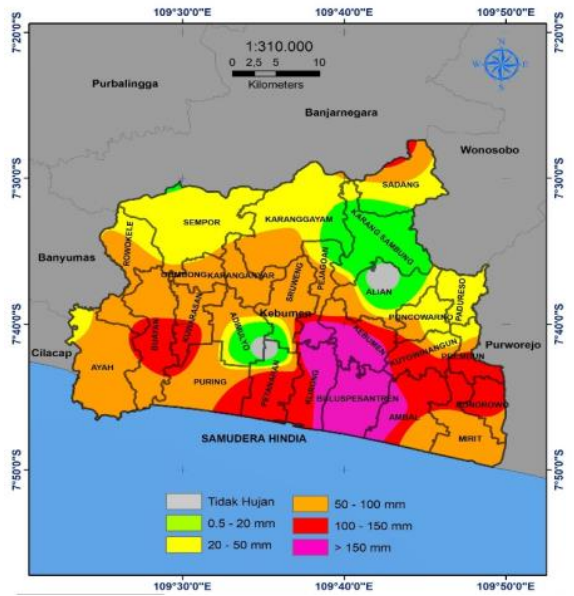

(a)

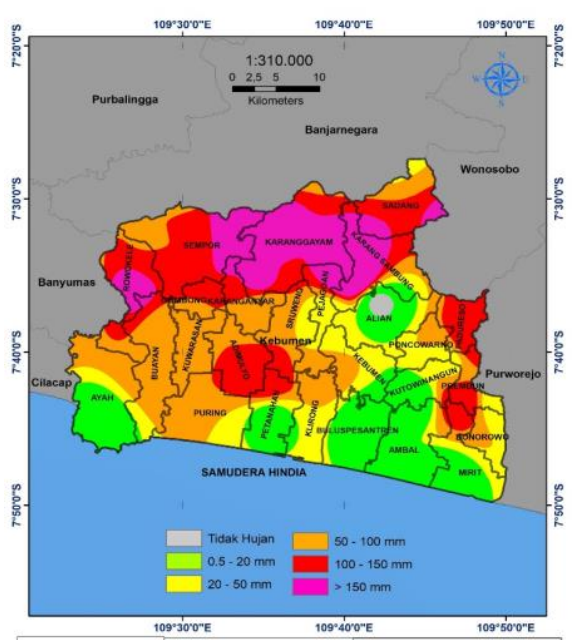

(c)

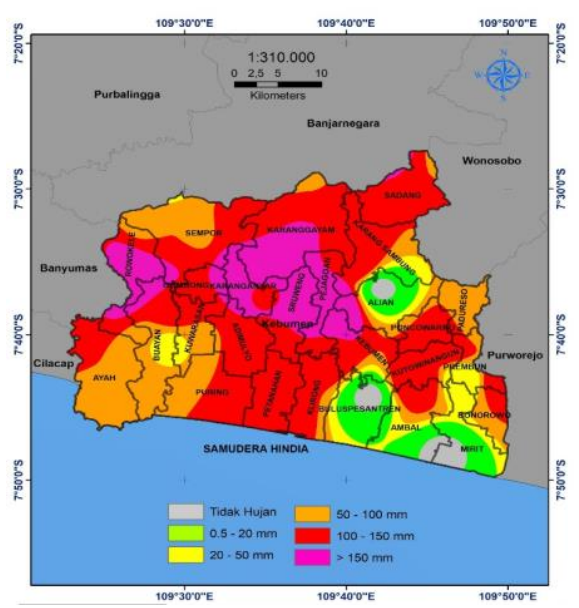

(e)

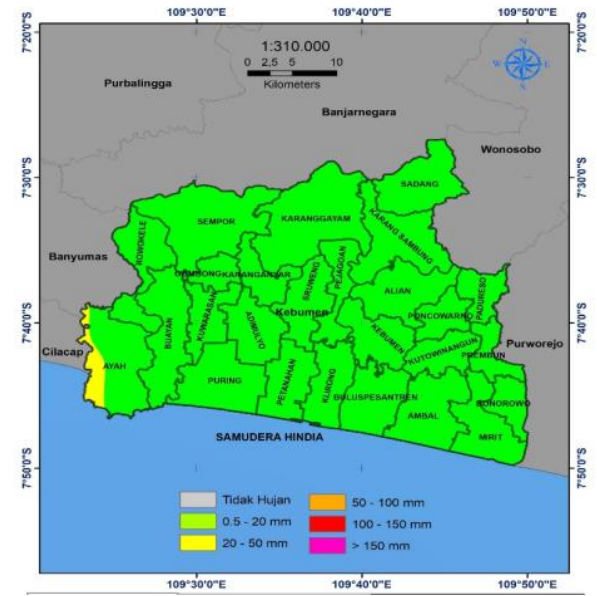

(b)

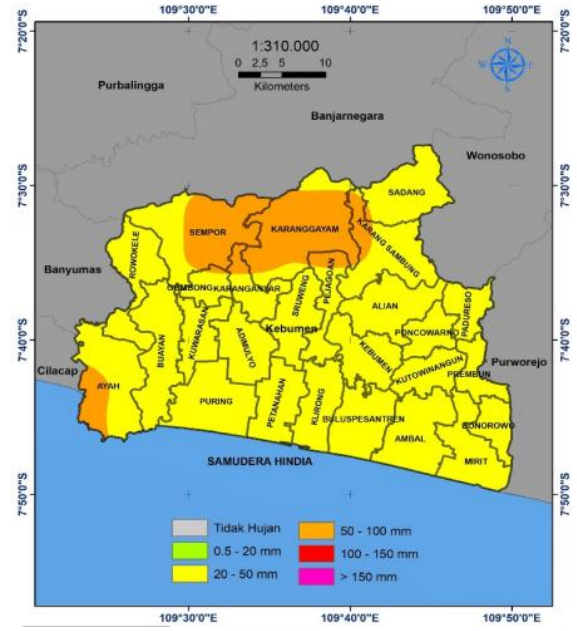

(d)

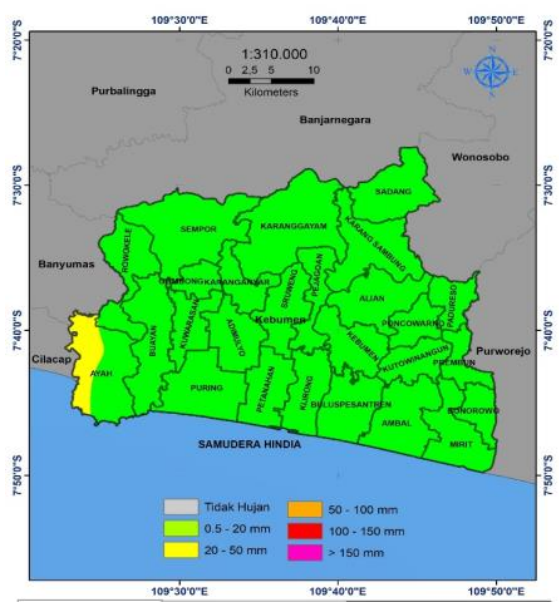

(f)

Gambar 4. Peta distribusi curah hujan Kabupaten Kebumen (a) Tanggal 24 Oktober 2020 (dicatat tanggal 25 Oktober 2020 pukul 07.00 WIB), (c) Tanggal 25 Oktober 2020 (dicatat tanggal 26 Oktober 2020 pukul 07.00 WIB), dan (e) Tanggal 26 Oktober 2020 (dicatat tanggal 27 Oktober 2020 pukul 07.00 WIB). Serta Peta Observasi Citra GSMap (JAXA) (b) jumlah presipitasi tanggal 24 Oktober 2020, (d) jumlah presipitasi tanggal 25 Oktober 2020 dan (f) jumlah presipitasi tanggal 26 Oktober 2020. 


\section{Analisa Hujan Dasarian Kabupaten Kebumen}

Pada Gambar 5, distribusi curah hujan kumulatif dasarian III Oktober 2020 menunjukkan hampir seluruh wilayah Kabupaten Kebumen berada dalam kategori sangat tinggi (>300 mm/dasarian) meliputi Kecamatan Rowokele, Sempor, Karanggayam, Sadang, Karangsembung, Padureso, Alian, Pejagoan, Karanganyar, Gombong, Kuwarasan, Buayan, Puring, Klirong, Buluspesantren, Ambal, Mirit, Bonorowo, Prembun, Kutowinangun, Kebumen, sebagian besar wilayah Kecamatan Sruweng, Adimulyo, Petanahan dan Ayah. Sedangkan sebagian wilayah Kecamatan Ayah dan Adimulyo, sebagian kecil wilayah Kecamatan Petanahan dan Sruweng dalam kategori tinggi (201 - 300 $\mathrm{mm}$ /dasarian). Dari analisis harian (Gambar 4) curah hujan ekstrim harian pada dasarian ini terkonsentrasi di bagian tenggara, utara dan tengah wilayah Kabupaten Kebumen. Wilayah selatan merupakan dataran rendah, sedangkan pada bagian utara berupa pegunungan dan perbukitan yang merupakan bagian dari rangkaian Pegunungan Serayu Selatan. Sementara itu di barat wilayah Gombong, terdapat Kawasan Karst Gombong Selatan sebuah rangkaian pegunungan kapur yang membujur hingga pantai selatan berarah utaraselatan, dengan kondisi beberapa wilayah merupakan daerah pantai dan perbukitan, sedangkan sebagian besar wilayah lainnya merupakan dataran rendah. Proses orografis dapat mempengaruhi pembentukan hujan di wilayah sekitar pegunungan di bagian utara, selain secara umum pengaruh mulai aktifnya monsun Asia di bulan Oktober dapat meningkatkan intensitas curah hujan, terutama di wilayah pegunungan dibanding wilayah dataran rendah dan daerah pantai.

Peta Luaran Prediksi Operasional, Luaran Model Statistik (Ensemble Mean Produk HyBMG) dan Luaran Model Dinamis (Ensemble Mean Produk ECMWF)

Prediksi Operasional

Stasiun Klimatologi Semarang mengeluarkan produk prakiraan curah hujan se-Jawa Tengah yang diperbarui setiap awal dasarian. Produk prakiraan tersebut merupakan produk luaran dari ensemble mean ECMWF terdiri dari prakiraan curah hujan dasarian deterministik kategorial (besaran curah hujan dengan kelas kisaran tertentu) dan prakiraan curah hujan probabilistik

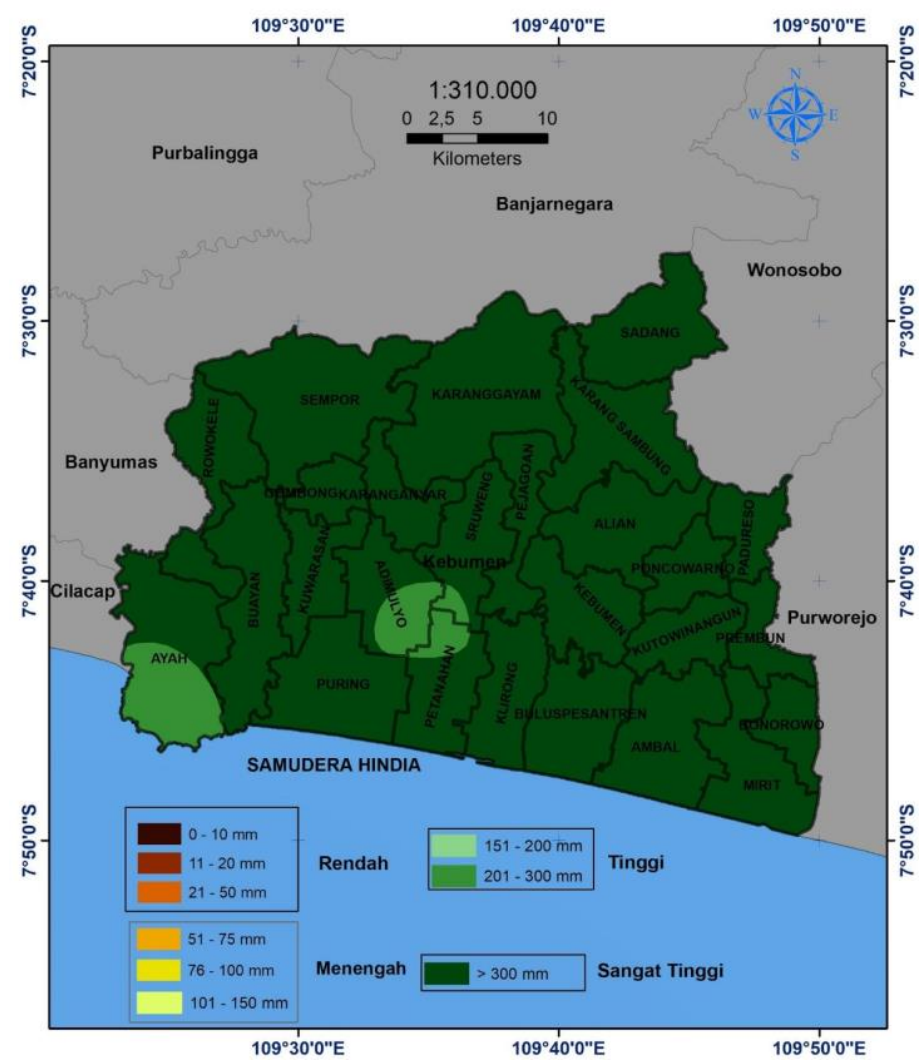

Gambar 5. Peta distribusi curah hujan Dasarian III Oktober 2020 Kabupaten Kebumen 

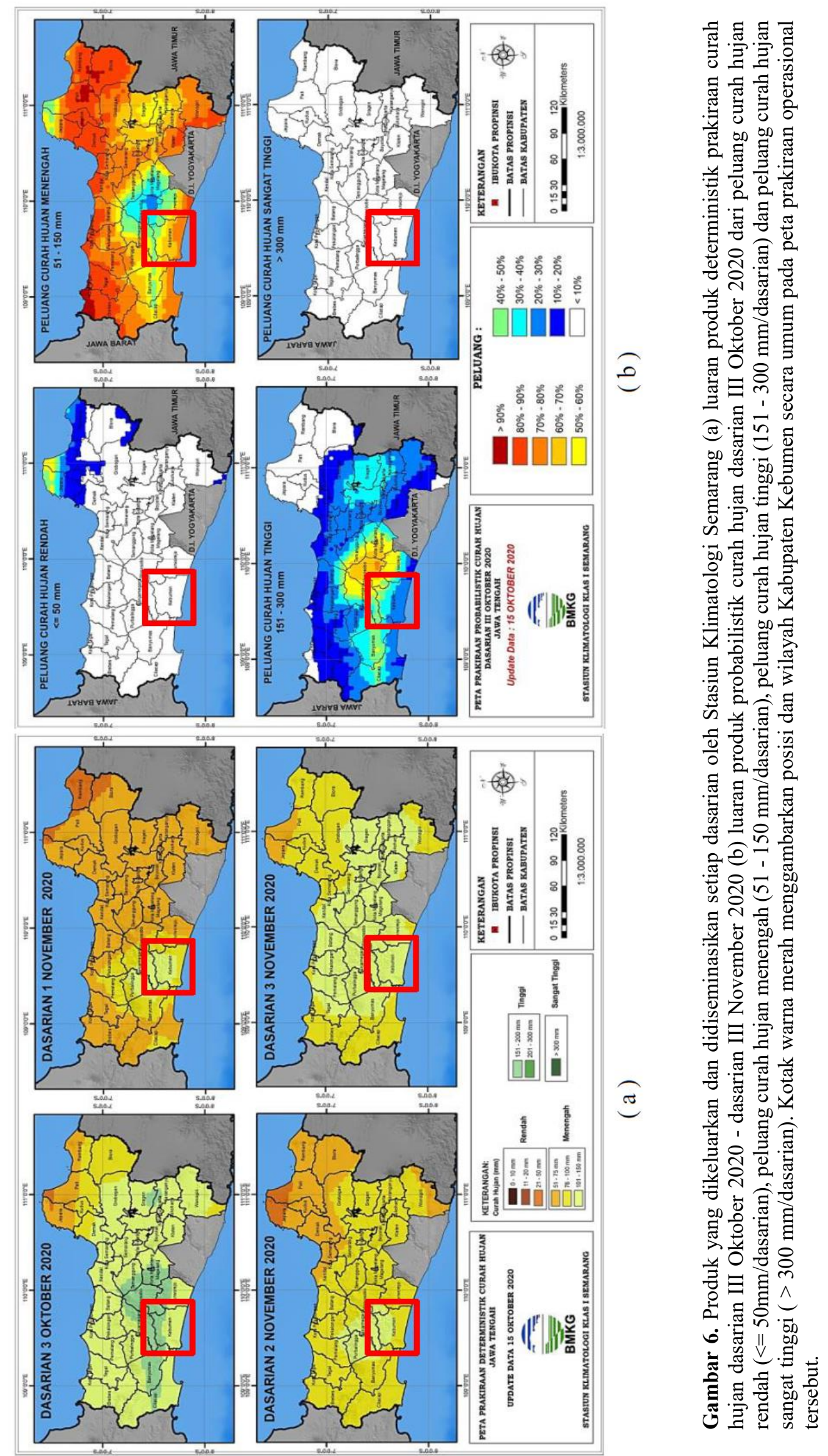
yang berbasis peluang untuk curah hujan di atas threshold (batasan) yang ditentukan (Gambar 6). Gambar 6(a) menunjukkan luaran produk deterministik pada dasarian III Oktober 2020 dimana secara spasial pada umumnya Jawa Tengah diprakirakan curah hujan dengan kriteria menengah (51-150 $\mathrm{mm} /$ dasarian) hingga tinggi (151-200 mm/dasarian). Di Kabupaten Kebumen, prakiraan curah hujan dasarian III Oktober 2020 mengindikasikan curah hujan kriteria tinggi (151$200 \mathrm{~mm}$ /dasarian) akan terjadi di wilayah Kabupaten Kebumen bagian Utara sedangkan curah hujan kategori menengah (101-150 $\mathrm{mm}$ /dasarian) diprakirakan terjadi di wilayah Kebumen bagian selatan.

Prakiraan yang dirilis satu dasarian sebelumnya ini berbeda dengan kondisi curah hujan sebenarnya dari analisis curah hujan dasarian III Oktober 2020 (Gambar 5) dimana curah hujan pada hampir sebagian besar wilayah memenuhi kriteria sangat tinggi $(>300$ $\mathrm{mm}$ /dasarian). Demikian halnya luaran prakiraan curah hujan probabilistik untuk dasarian III Oktober 2020 di Jawa Tengah, Gambar 6(b) mengindikasikan curah hujan menengah (51-150 $\mathrm{mm}$ /dasarian) lebih berpeluang tinggi dengan kisaran $70 \%$ hingga $>90 \%$, sedangkan untuk Kabupaten Kebumen curah hujan kategori menengah (101-150 $\mathrm{mm} /$ dasarian) berpeluang tinggi dengan kisaran $60 \%-80 \%$ di wilayah Kebumen bagian selatan, sedangkan peluang curah hujan rendah, tinggi dan sangat tinggi memiliki peluang curah hujannya rendah.

Berdasarkan analisis tersebut, perlu dilakukan penyelidikan kembali terhadap model-model individua mana yang memiliki keandalan lebih baik untuk memprakirakan kondisi curah hujan ekstrim seperti kasus yang terjadi di Kabupaten Kebumen ini, sehingga ke depan dapat dipergunakan sebagai pertimbangan untuk memperbaiki produk prakiraan curah hujan operasional.

\section{Prediksi Luaran Model Statistik (HyBMG)}

Gambar 7 (a) merupakan hasil perkiraan dari ensemble mean luaran model statistik HyBMG. Sebagian besar wilayah Kabupaten Kebumen bagian barat dan tengah diprakirakan akan mendapatkan curah hujan dalam kriteria tinggi (151-200 $\mathrm{mm} /$ dasarian), tertinggi di sebagian wilayah Kecamatan Sempor diperkirakan curah hujan kriteria tinggi berkisar antara 200-300 $\mathrm{mm}$ /dasarian, sedangkan untuk Kecamatan
Sadang, Padureso, Prembun, Bonorowo, Mirit, Sebagian wilayah Kecamatan, Karangsembung, Poncowarno, Kutowinangun, dan Ambal, sebagian kecil wilayah Kecamatan Karanggayam dan Alian diperkirakan curah hujan dengan kriteria menengah berkisar antara 101-150 $\mathrm{mm}$ /dasarian. Meskipun masih cenderung underestimate terhadap analisis curah hujan dasarian pada Gambar 5, prakiraan ensemble mean luaran HyBMG ini setidaknya dapat menangkap intensitas tinggi dari curah hujan dan dapat menggambarkan secara lebih bagus daripada luaran prediksi operasional tersebut. Selanjutnya akan diselidiki terhadap performansi model-model statistik secara individual yang ada di HyBMG .

Gambar 7 (b) menunjukkan hasil prakiraan curah hujan luaran model ARIMA untuk dasarian III Oktober. Curah hujan kriteria tinggi (200-300 $\mathrm{mm}$ /dasarian) tampak diprakirakan meliputi sebagian Kecamatan Sempor, Sebagian Kecil Rowokele. Curah hujan di sebagian besar wilayah Kabupaten Kebumen diperkirakan akan berada pada kisaran 151-200 $\mathrm{mm} /$ dasarian termasuk dalam kriteria curah hujan tinggi. Sedangkan untuk Kecamatan Bonorowo dan Gombong, sebagian besar wilayah Kecamatan Mirit dan Prembun, sebagian kecil wilayah Kecamatan Padureso, Sempor, Karanganyar, Adimulyo dan Kuwarasan diperkirakan curah hujan kriteria menengah dengan kisaran 101-150 $\mathrm{mm} /$ dasarian.

Sementara untuk hasil prakiraan luaran ANFIS (Gambar 7 (c)), curah hujan kriteria tinggi (200-300 $\mathrm{mm} /$ dasarian) diprakirakan akan meliputi sebagian besar wilayah Kecamatan Sempor dan Rowokele, sebagian wilayah Kecamatan Buayan, Karanggayam dan Sruweng, sebagian kecil wilayah Kecamatan Karanganyar. Sebagian besar wilayah Kabupaten Kebumen diperkirakan kisaran 151-200 $\mathrm{mm} /$ dasarian termasuk dalam kriteria curah hujan tinggi. Sedangkan untuk Kecamatan Bonorowo, sebagian besar wilayah Kecamatan Mirit, Padureso, Sadang, sebagian kecil wilayah Kecamatan Karanggayam, Karangsembung, Alian, Poncowarno, Kutowinangun diprakirakan curah hujan kriteria menengah dengan kisaran 101-150 mm/dasarian. Sebagian kecil wilayah Kecamatan Sadang diperkirakan curah hujan dalam kisaran 76-100 $\mathrm{mm} /$ dasarian. Hasil prakiraan luaran ARIMA dan ANFIS memiliki prediktabilitas yang lebih tinggi dalam 


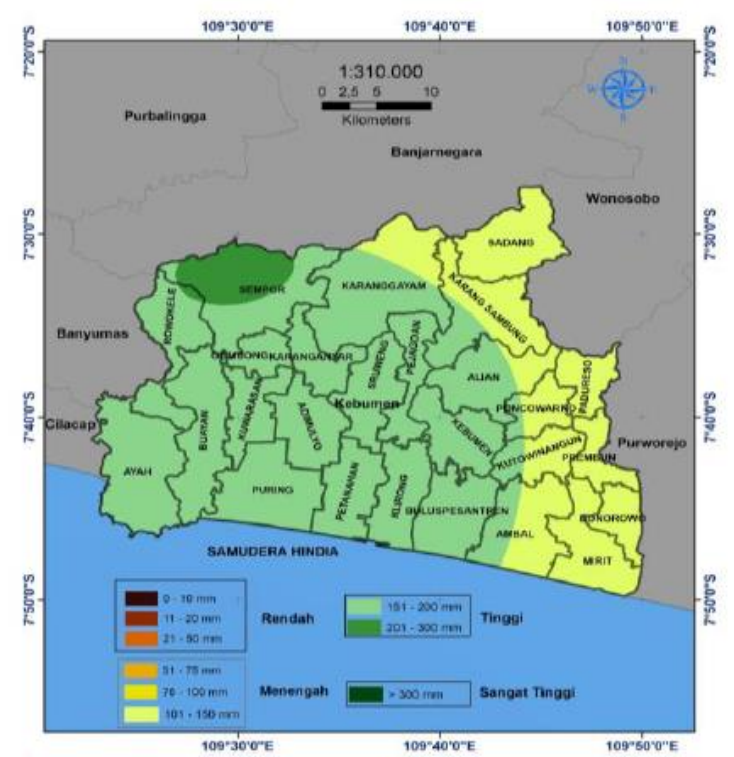

(a)

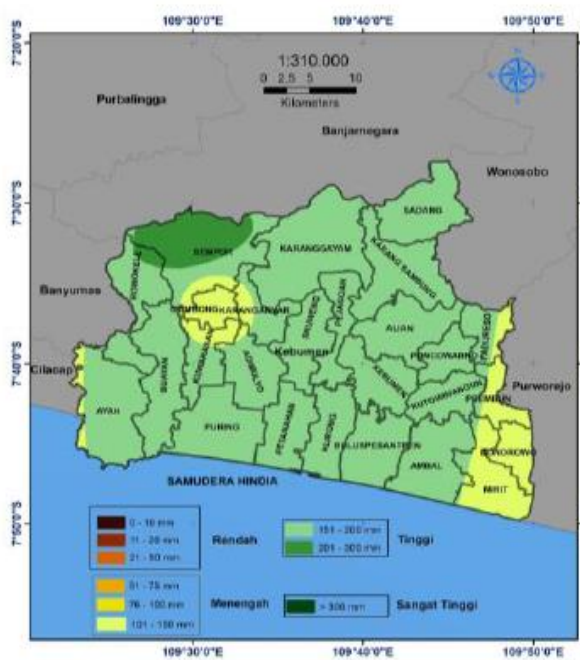

(b)

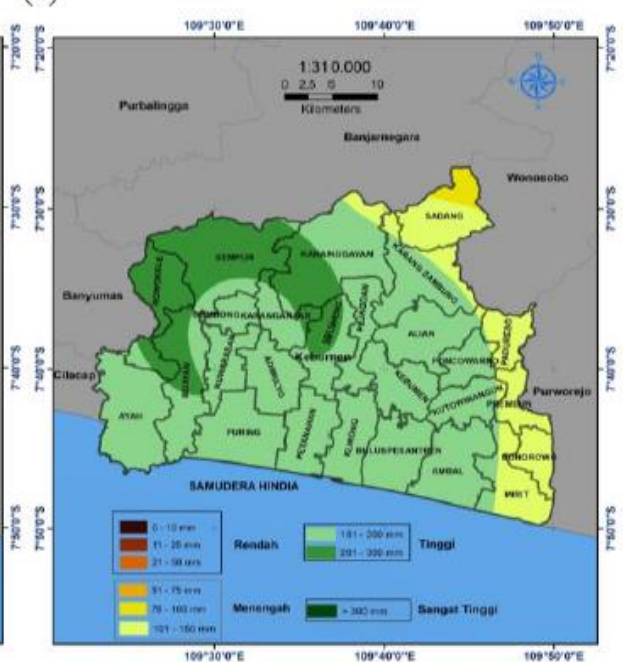

(c)

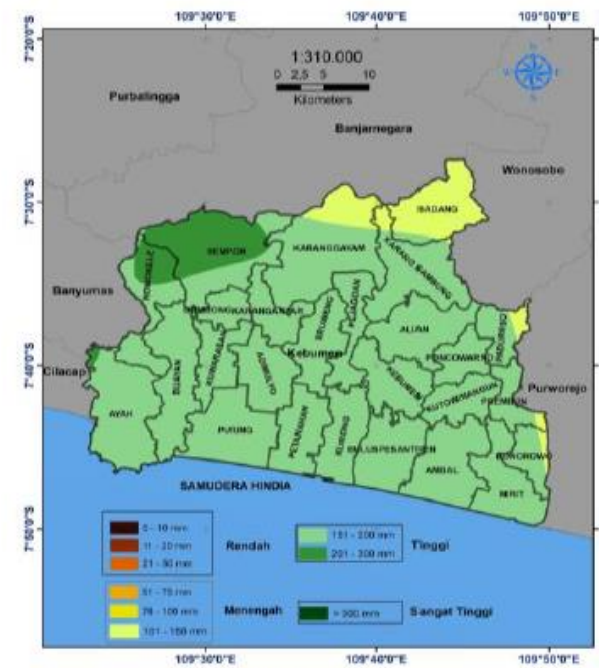

(c)

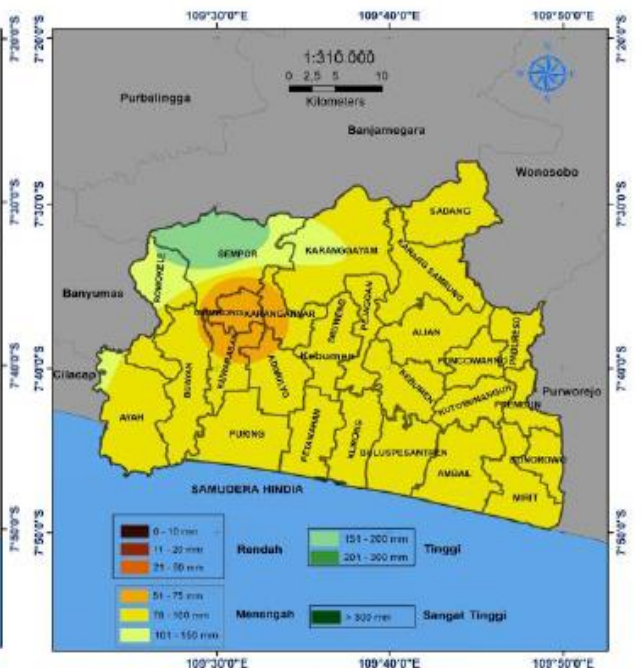

(d)

Gambar 7. Peta prakiraan curah hujan Dasarian III Oktober 2020 Kabupaten Kebumen (a) Ensemble Mean HyBMG, (b) ARIMA, (c) ANFIS (d) Wavelet-ANFIS (e) Wavelet-ARIMA. 
mengidentifikasi curah hujan tinggi yang mendekati curah hujan observasi. Meskipun, bias prakiraan - observasi masih cukup besar untuk cura hujan kriteria tinggi, sebagai contoh untuk Kecamatan Gombong.

Hasil prakiraan curah hujan luaran WaveletANFIS (Gambar 7 (d)) dari untuk hampir seluruh wilayah Kabupaten Kebumen diperkirakan dengan curah hujan kriteria tinggi dengan kisaran 151-200 $\mathrm{mm} /$ dasarian, dengan curah hujan tertinggi dengan kisaran $201-300 \mathrm{~mm} /$ dasarian meliputi sebagian wilayah Kecamatan Sempor, sebagian kecil wilayah Kecamatan Rowokele dan Ayah. Curah hujan kriteria menengah (101 - 150 $\mathrm{mm}$ /dasarian) diprakirakan meliputi sebagian besar wilayah Kecamatan Sadang, sebagian kecil wilayah Kecamatan Karanggayam, Karangsambung, Padureso, Prembun dan Bonorowo.

Gambar 7 (e) menunjukkan hasil prakiraan luaran Wavelet-ARIMA masih memiliki bias cukup besar bila dibandingkan dengan luaran prakiraan sebelumnya, yaitu hampir seluruh wilayah Kabupaten Kebumen diperkirakan curah hujan dengan kriteria menengah dengan kisaran antara 51-150 $\mathrm{mm} /$ dasarian. Hanya sebagian wilayah Kecamatan Sempor diperkirakan mendapatkan curah hujan kriteria tinggi (151$200 \mathrm{~mm}$ /dasarian), konsisten dengan prakiraan curah hujan kriteria tinggi luaran dari Ensemble Mean HyBMG untuk Kecamatan Sempor.

\section{Prediksi Luaran Model Dinamis (ECMWF)}

Luaran model dinamis ECMWF yang dikaji dalam penelitian ini terdiri dari prakiraan luaran deterministik dan probabilistik yang dihasilkan dari 51 member run ECMWF (Gambar 8). Gambar 8 (a) menunjukkan hasil prakiraan luaran deterministik ensemble means ECMWF. Hampir sebagian besar wilayah Kabupaten Kebumen diprakirakan dalam kriteria menengah dengan curah hujan berkisar antara $101-150$ $\mathrm{mm}$ /dasarian, sedangkan untuk Kecamatan Sempor, Gombong, wilayah Kecamatan Rowokele, Kuwarasan, Karanganyar,
Karanggayam, Sadang dan sebagian kecil wilayah Kecamatan Karangsembung, Alian, Padureso dalam kriteria Tinggi yaitu berkisar antara 151-200 mm/dasarian.

Gambar 8 (b) menunjukkan luaran prakiraan probabilistik untuk peluang curah hujan rendah $(<50 \mathrm{~mm} /$ dasarian) di seluruh wilayah Kabupaten Kebumen adalah $<10 \%$ yang artinya berpeluang sangat rendah. Untuk curah hujan menengah (51$150 \mathrm{~mm} /$ dasarian) sebagaimana pada Gambar 8 (c), terdapat peluang tinggi pada kisaran 70\%80\% meliputi wilayah Kecamatan Petanahan, Klirong, Buluspesantren, Ambal, Mirit dan Bonorowo; sebagian wilayah Kecamatan Ayah, Puring, Kebumen dan Kutowinangun; sebagian kecil wilayah Kecamatan Buayan, Adimulyo, Sruweng, Pejagoan, Prembun dan Poncowarno. Curah hujan menengah dengan peluang cukup tinggi dengan kisaran 60\% - 70\% meliputi wilayah Kecamatan Kuwarasan dan Gombong; sebagian besar wilayah Kecamatan Prembun, Poncowarno, Sruweng, Karanganyar, Adimulyo, Buayan dan Rowokele; sebagian wilayah Kecamatan Ayah, Puring, Pejagoan, Alian, Kebumen dan Padureso; sebagian kecil wilayah Kecamatan Sempor, Karanggayam dan Karangsembung. Sebagian wilayah Kecamatan Rowokele, Sempor, Karanggayam, Karangsembung, Sadang dan Padureso dalam kisaran dibawah $60 \%$ peluang potensi curah hujan menengah dianggap rendah.

Peluang kejadian curah hujan tinggi (151 - 300 $\mathrm{mm}$ /dasarian) seluruh wilayah kecamatan di Kabupaten Kebumen berada pada kisaran peluang cukup rendah dibawah $60 \%$ (Gambar 8 (d)). Gambar 8 (e) menunjukkan peluang sangat rendah $<10 \%$ untuk curah sangat tinggi $(>300$ $\mathrm{mm} /$ dasarian) di seluruh wilayah Kabupaten Kebumen. Dari produk ensemble means ECMWF baik dari luaran deterministik dan probabilistik secara umum hasil prakiraan curah hujan pada dasarian III Oktober 2020 di wilayah Kabupaten Kebumen berada dalam kategori menengah (51-150 $\mathrm{mm} /$ dasarian). 


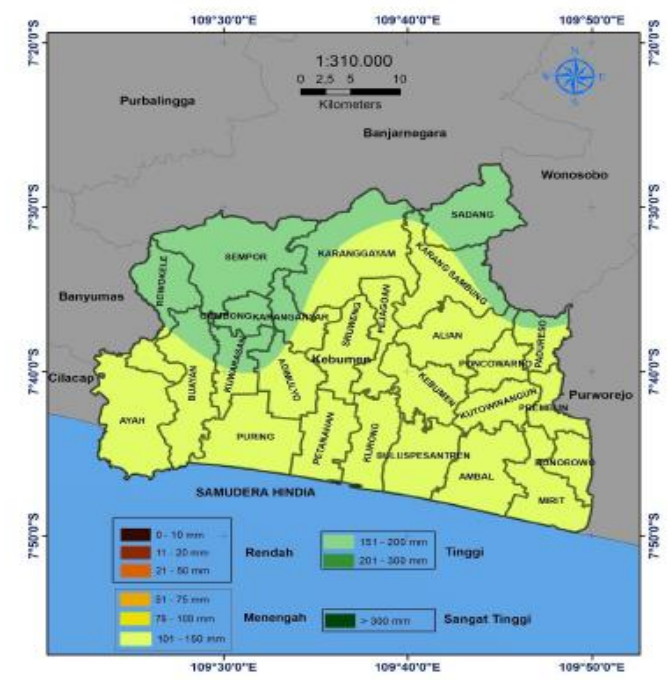

(a)

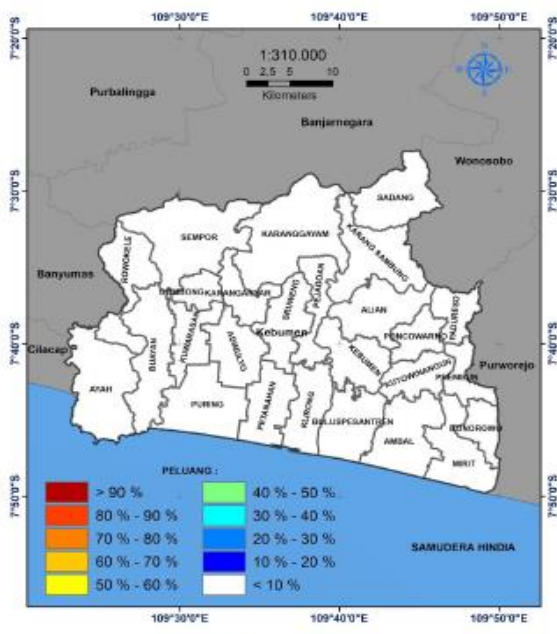

(b)

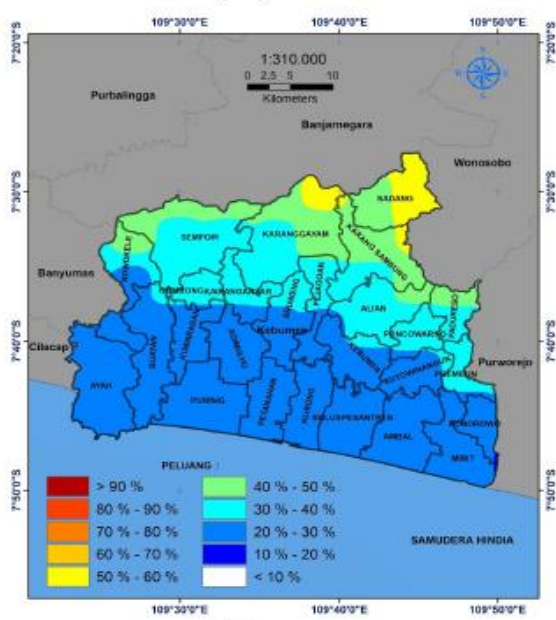

(d)

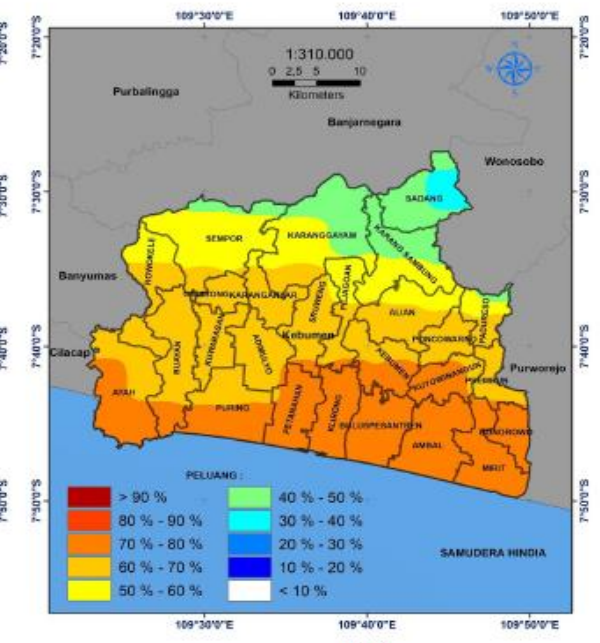

(c)

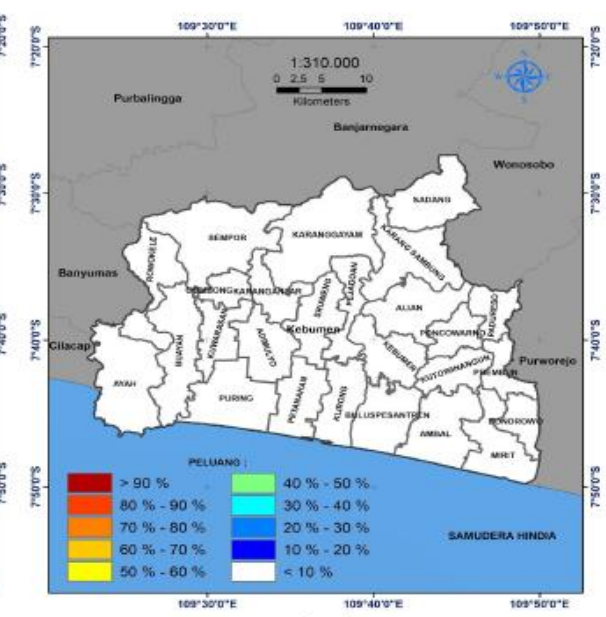

(e)

Gambar 8. Peta prakiraan curah hujan dasarian III Oktober 2020 Kabupaten Kebumen luaran model dinamis ECMWF (a) luaran deterministik ensemble mean (b) luaran probabilistik peluang curah hujan rendah (c )luaran probabilistik peluang curah hujan menengah (d) luaran probabilistik peluang curah hujan tinggi (e) luaran probabilistik peluang curah hujan sangat tinggi 


\section{PEMBAHASAN}

Kejadian banjir di Kabupaten Kebumen tanggal 26 Oktober 2020 dipicu oleh hujan dengan intensitas sangat lebat hingga ekstrim yang berlangsung sejak Minggu (25 Oktober 2020) sore hingga Senin (26 Oktober 2020). Beberapa pos pengamatan hujan (kerjasama) menunjukkan curah hujan $>150 \mathrm{~mm} /$ hari (kategori ekstrim) dalam rentang waktu hujan tanggal 24-26 Oktober 2020. Analisis curah hujan akumulatif dasarian ke-III Oktober 2020 di wilayah Kabupaten Kebumen menunjukkan curah hujan $>300 \mathrm{~mm} /$ dasarian (kriteria sangat tinggi). Dampak nyata dari curah hujan ekstrim tersebut adalah terjadi banjir yang luas di wilayah Kabupaten Kebumen, yang mengakibatkan kerugian besar bagi masyarakat di wilayah terdampak.

Sepuluh hari (1 dasarian) sebelumnya, BMKG Stasiun Klimatologi Semarang memprakirakan curah hujan akumulatif pada dasarian ke-III Oktober 2020 untuk sebagian besar wilayah Kabupaten Kebumen akan berkisar antara 101$150 \mathrm{~mm} /$ dasarian (kriteria menengah), sedangkan untuk Kecamatan Sempor, Gombong, sebagian wilayah Kecamatan Rowokele, Kuwarasan, Karanganyar, Karanggayam, Sadang dan sebagian kecil wilayah Kecamatan Karangsembung, Alian, Padureso berkisar antara 151-200 $\mathrm{mm} /$ dasarian (kriteria tinggi). Curah hujan pada dasarian ke-III Oktober 2020 di Jawa Tengah secara umum diprakirakan berada pada kriteria menengah hingga tinggi mengingat aktifnya fenomena anomali iklim global La Niña di Samudera Pasifik ekuator.

La Niña umumnya berpengaruh terhadap meningkatnya curah hujan di wilayah Indonesia pada bulan September-Oktober-November (SON), terutama bagian tengah hingga timur 20$40 \%$ lebih tinggi dibandingkan curah hujan saat tahun normal (Supari dkk., 2018; Pusat Informasi Perubahan Iklim, 2020). Respon tiap wilayah terhadap fenomena La Niña berbeda-beda tergantung kepada waktu (bulan), lokasi (wilayah) dan terhadap intensitas La Niña itu sendiri, apakah La Niña lemah, moderate atau kuat (Pusat Informasi Perubahan Iklim, Kedeputian Klimatologi, 2020). Seperti di Jakarta, pada saat memasuki puncak musim hujan di bulan Desember dengan latar belakang kondisi La Niña justru curah hujan akumulatifnya menunjukkan indikasi bawah normal (Siswanto dkk., 1999; Supari dkk., 2018). Musim hujan tahun 2020/2021 kali ini diwarnai oleh latar belakang fenomena iklim global La Nina yang terjadi sejak awal Oktober 2020 dan diprediksi akan berlangsung hingga Mei 2021 dengan intensitas La Nina Moderat menjadi La Nina Lemah pada Maret 2021 (BMKG, 2020). Kejadian La Nina dengan intensitas moderate kuat terjadi 11 kali dalam periode 30 tahun terakhir, dan dapat dikaitkan dengan curah hujan di atas normal di Kabupaten Kebumen secara umum. Sehingga, meskipun tidak dapat dikatakan sebagai penyebab langsung kejadian individual curah hujan ekstrem di Kabupaten Kebumen, La Niña dapat meningkatkan peluang kejadian ekstrim tersebut untuk terbentuk.

\section{Perbandingan, Uji Korelasi dan Error Statistik (RMSE) Luaran Prakiraan Terhadap Analisis Hasil Observasi}

Gambar 9 menunjukkan grafik perbandingan curah hujan hasil prakiraan ECMWF dengan hasil observasi di Kabupaten Kebumen untuk 13 pos hujan yang mewakili pada dasarian III bulan Oktober 2020. Pada Gambar 9 (a) terlihat bahwa prakiraan luaran ECMWF berada pada kriteria menengah hingga tinggi dengan kisaran 101-200 $\mathrm{mm}$ /dasarian sedangkan analisis curah hujan observasi berada pada kriteria tinggi hingga sangat tinggi (151 hingga $>300 \mathrm{~mm} /$ dasarian bahkan ada beberapa pos hujan tercatat curah hujannya sangat ekstrim $>500 \mathrm{~mm} /$ dasarian. Bias cukup nyata tampak antara keduanya, dimana curah hujan hasil observasi lebih variatif dibandingkan ECMWF yang memiliki pola curah hujan cenderung datar dalam rentang 101-200 $\mathrm{mm}$ /dasarian, meskipun kesamaan pola antara keduanya masih dapat dikenali.

Sebagaimana pada Gambar 9 (a), Gambar 9 (b) merupakan grafik perbandingan curah hujan hasil prakiraan ensemble mean HyBMG dengan hasil observasi. Fluktuasi nilai prakiraan curah hujan memiliki pola yang relatif mirip dengan hasil observasi, kecuali di pos hujan BPP kesugihan dan Wanadadi yang memperlihatkan pola terbalik. Hasil prakiraan ensemble mean HyBMG berada pada kriteria menengah hingga tinggi 101-200 mm/dasarian.

Gambar 9 (c) merupakan grafik perbandingan curah hujan hasil prakiraan ANFIS dengan data observasi. Fluktuasi nilai prakiraan curah hujan memiliki pola yang relatif mirip dengan hasil observasi, kecuali di pos hujan BPP kesugihan 
dan Wanadadi yang memperlihatkan pola terbalik.

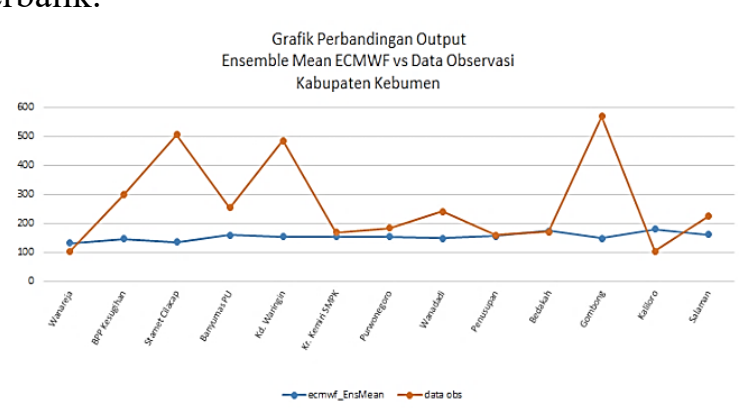

( a )

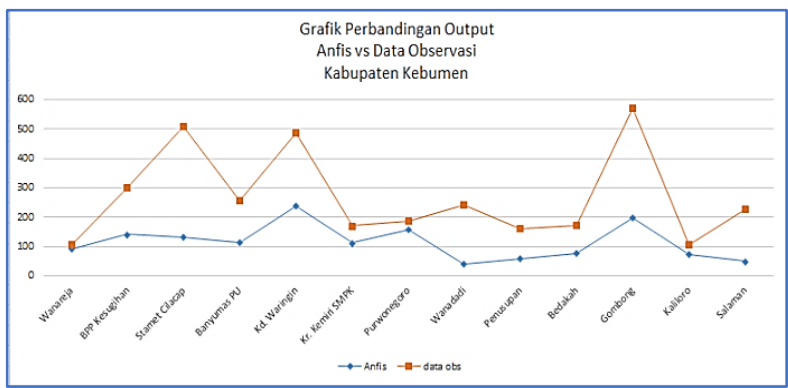

( c )

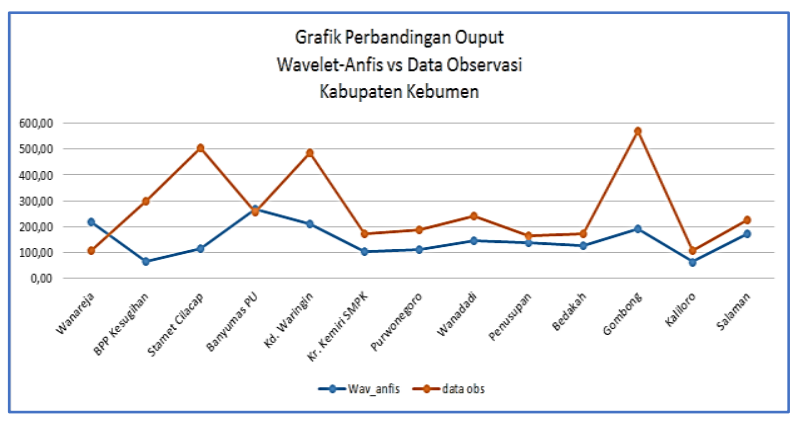

( e )

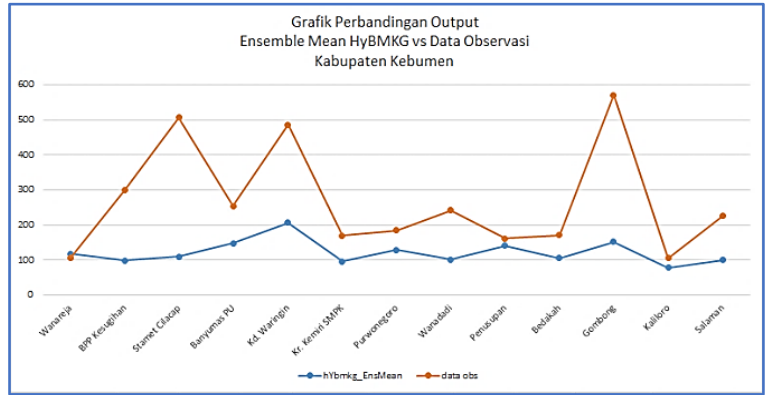

( b )

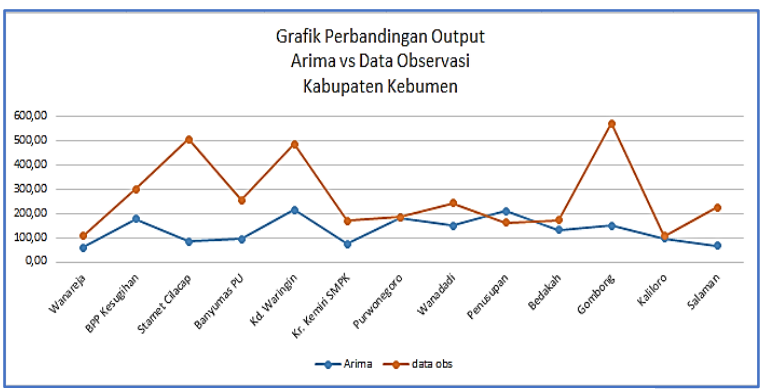

( d )

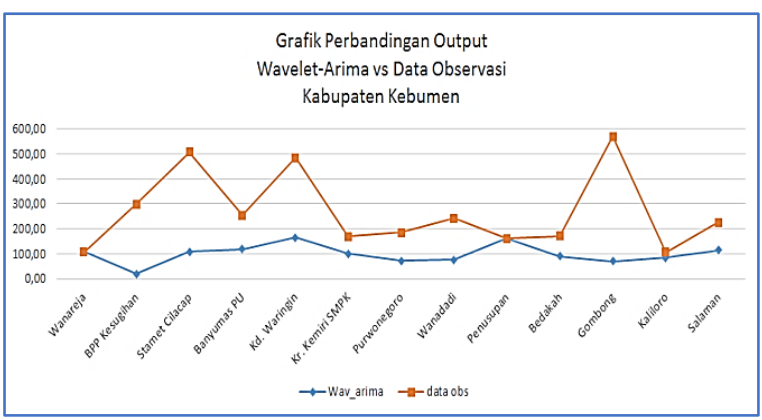

( f)

Gambar 9. Grafik perbandingan hasil prakiraan dengan observasi di Kabupaten Kebumen (a) Ensemble Mean ECMWF dengan Observasi, (b) Ensemble Mean HyBMG dengan Observasi, (c) ANFIS dengan Observasi, (d) ARIMA dengan Observasi, (e) Wavelet-ANFIS dengan Observasi, (f) Wavelet-ARIMA dengan Observasi.

Pola fluktuasi prakiraan versus observasi yang lebih mirip juga digambarkan oleh luaran model ARIMA (Gambar 9 (d)). Pola terbalik ditemukan untuk pos hujan Stamet Cilacap, Wanadadi dan Penusupan. Curah hujan luaran ARIMA berada pada kriteria menengah hingga tinggi (50 sampai $>200 \mathrm{~mm} /$ dasarian).

Performansi luaran prakiraan curah hujan metode Wavelet-ANFIS ditunjukkan oleh Gambar 9 (e). Pola fluktuasi prakiraan versus observasi relatif mirip, dengan curah hujan berada pada kriteria menengah hingga tinggi (50 sampai $>200 \mathrm{~mm} /$ dasarian), kecuali pada pos hujan Wanareja. Luaran prakiraan metode Wavelet-ANFIS cenderung over estimate terhadap nilai observasinya, sedangkan untuk luaran model Wavelet-ARIMA dengan data observasi wilayah Kabupaten Kebumen. Pola fluktuasi prakiraan versus observasi relatif mirip, namun curah hujan prakiraan cenderung lebih rendah dari pada hasil model prakiraan lainnya dengan kriteria rendah hingga menengah 20-151 $\mathrm{mm} /$ dasarian.

Perbandingan visual antara hasil prakiraan Ensemble Mean ECMWF dan luaran HyBMG (Ensemble Mean HyBMG, ARIMA, ANFIS, Wavelet-ANFIS, Wavelet-ARIMA) terhadap nilai observasi selanjutnya dikuantifikasi tingkat hubungannya dengan uji korelasi. Tabel 2 menjelaskan bahwa nilai korelasi antara 
prakiraan ensemble mean ECMWF terhadap nilai observasi memiliki hubungan negatif Tabel 2. Korelasi prakiraan Ensemble Mean ECMWF dan hasil Univariat dari Aplikasi HyBMG (Ensemble Mean HyBMG, ARIMA, ANFIS, Wavelet-ANFIS, Wavelet-ARIMA) dengan hasil observasi

\begin{tabular}{|l|c|c|l|}
\hline \multicolumn{1}{|c|}{$\begin{array}{c}\text { OBSERVASI vs } \\
\text { PRAKIRAAN }\end{array}$} & NILAI KORELASI & RMSE & \multicolumn{1}{c|}{ INTERPRETASI } \\
\hline $\begin{array}{l}\text { ENSEMBLE MEAN ECMWF } \\
\text { vs OBS }\end{array}$ & $-0,368850032$ & 405,93 & $\begin{array}{l}\text { hubungan korelasi berlawanan } \\
\text { dan memiliki error paling } \\
\text { rendah }\end{array}$ \\
\hline $\begin{array}{l}\text { ENSEMBLE MEAN HyBMG } \\
\text { vs OBS }\end{array}$ & 0,539497851 & 524,92 & $\begin{array}{l}\text { hubungan korelasi sedang dan } \\
\text { memiliki error cukup besar }\end{array}$ \\
\hline ANFIS vs OBS & 0,721311754 & 556,5 & $\begin{array}{l}\text { hubungan korelasi kuat dan } \\
\text { memiliki error cukup besar }\end{array}$ \\
\hline ARIMA vs OBS & 0,261931263 & 466,9 & $\begin{array}{l}\text { hubungan korelasi rendah dan } \\
\text { memiliki error cukup rendah }\end{array}$ \\
\hline WAVELET-ANFIS vs OBS & 0,235860976 & 435,61 & $\begin{array}{l}\text { hubungan korelasi rendah dan } \\
\text { memiliki error cuku rendah }\end{array}$ \\
\hline WAVELET ARIMA vs OBS & 0,03395055 & 607,67 & $\begin{array}{l}\text { hubungan korelasi diabaikan } \\
\text { dan memiliki error paling besar }\end{array}$ \\
\hline
\end{tabular}

hampir semua model.

Terdapat dua luaran prakiraan yang memiliki korelasi terbaik, yaitu luaran ensemble mean HyBMG dengan korelasi 0,539 (korelasi sedang) dan luaran ANFIS dengan korelasi 0,721 (hubungan korelasi kuat). Hubungan korelasi rendah ditunjukkan oleh luaran model ARIMA dan Wavelet-ANFIS.

Analisis bias prakiraan versus observasi ditunjukkan oleh nilai RMSE yang menunjukkan besarnya penyimpangan yang terjadi antara nilai prediksi hasil masing-masing metode dengan data observasi. Semakin besar nilai RMSE maka dapat dikatakan semakin besar pula penyimpangannya, sedangkan sebaliknya nilai RMSE yang diharapkan adalah yang paling kecil artinya penyimpangannya pun akan semakin kecil. Pada tabel 2 diatas nilai RMSE untuk ensembel mean ECMWF adalah sebesar 405,93; ensemble mean HyBMG sebesar 524,92. RMSE model statistik individual untuk model ANFIS adalah sebesar 556,5; model ARIMA sebesar 499,9; model Wavelet-ANFIS adalah 435,61 sedangkan model Wavelet-ARIMA adalah sebesar 607,67.

Dalam analisis korelasi dan RMSE dapat dilihat secara khusus bahwa korelasi terbesar dimiliki oleh luaran prakiraan model ANFIS (Gambar 7 c)) dengan nilai RMSE yang juga cukup besar namun tidak lebih besar jika dibandingkan nilai RMSE luaran prakiraan model WAVELET ARIMA, dengan demikian faktor koreksi diperlukan dalam penelitian selanjutnya.

\section{KESIMPULAN}

Metode yang selama ini digunakan untuk memprediksi ekstremitas curah hujan baik secara spasial maupun besaran intensitasnya pada kejadian curah hujan ekstrim pemicu banjir di Kabupaten Kebumen masih belum cukup berhasil sebagai luaran prakiraan operasional. Hal ini membuka peluang riset-riset eksperimental untuk merumuskan metode yang lebih tepat yang dapat digunakan sebagai dasar luaran prediksi operasional.

Upaya eksperimental kami, berdasarkan perbandingan visual untuk kesesuaian spasial serta analisis korelasi dan RMSE berhasil menunjukkan luaran prakiraan model statistik ANFIS dengan sensitivitas prediksi yang lebih handal dibandingkan luaran model statistik maupun dinamis lainnya. Metode ini dapat menyajikan prakiraan kejadian hujan ekstrim pada hari Minggu (25 Oktober 2020) di Kabupaten Kebumen dengan lebih presisi.

Namun demikian beberapa saran sebagai berikut sangat penting untuk upaya eksperimental selanjutnya:

1. Perlunya penambahan input seri data yang lebih panjang perhitungan faktor koreksi antara nilai prediksi dengan nilai observasinya 
sebagai salah satu acuan perumusan nilai prediksi.

2. Perlu eksperiman yang fokus untuk menguji akurasi produk citra estimasi GSMaP. Pembandingnya adalah distribusi data curah hujan overestimate atau underestimate.

\section{DAFTAR PUSTAKA}

Apriyana, Y. dan Kailaku, T. E., 2015. Variabilitas iklim dan dinamika waktu tanam padi di wilayah pola hujan monsunal dan equatorial. Prosiding Seminar Nasional Masyarakat Biodiv Indonesia, 1(2), hal.366-372, 2015.

Arini Wahyu Utami, Jamhari, dan Suhatmini Hardyastuti, 2011. El Nino, La Nina, Dan Penawaran Pangan Di Jawa, Indonesia. Jurnal Ekonomi Pembangunan Volume 12, Nomor 2, Desember 2011, hlm.257-271, Jurnal Ilmiah Universitas Muhammadiyah Surakarta.

BMKG (Badan Meteorologi, Klimatologi, dan Geofisika), 2020a. BMKG Ingatkan Prospek Iklim 2021. https://www.bmkg.go.id/pressrelease/?p=bmkg-ingatkan-prospek-iklim2021\&tag=press-release\&lang=ID

BNPB (Badan Nasional Penanggulangan Bencana), 2021. Data dan Informasi Bencana Indonesia (DIBI) di Kabupaten Kebumen.

http://dibi.bnpb.go.id/DesInventar/results.js p. Diakses tanggal 18 Februari 2021.

ECMWF (The European Centre for MediumRange Weather Forecasts), 2016. Who we are. http://www.ecmwf.int/en/about/whowe-are. Diakses pada hari Kamis 04 Februari2021 pukul 11.30 WIB.

Heksantoro, R., 2020. Banjir Landa Kebumen, Warga di Sejumlah Desa Sempat Mengungsi. https://news.detik.com/beritajawa-tengah/d-5229090/banjir-landa-kebumenwarga-di-sejumlah-desa-sempatmengungsi?_ga $=2.199101935 .1986449904 .161$ 2239388-1984205331.1593998604. Diakses tanggal 2 Februari 2021.

Iriawan, N. dan Astuti, S.P., 2006. Mengolah Data Statistik dengan mudah menggunakan Minitab 14. Yogyakarta: ANDI. Hal.341.

Jang, J.S.R., 1993). ANFIS: AdaptiveNeuralNetwork-Based-Fuzzy Inference System. IEEE Transactions On Systems,Ma, And Cybernetics, Vol. 23 No 3, May/June 1993.
Gogtay, N.J.dan Thatte, U.M., 2017. Principles of Correlation Analysis. Journal of the Association of Physicians of India, 65, hal.78-80

Komalasari, K.E., Fajarina, Y., Nuraini, T.A., Anggraeni, R., 2016. Aplikasi Metode Ensemble Mean Untuk Meningkatkan Reliabilitas Prediksi HyBMG. Jurnal Meteorologi dan Geofisika, 17(1), hal.4752. DOI: 10.31172/jmg.v17i1.381

Mardianto, I, Gunawan, M.I., Sugiarto, D, Rochman, A., 2021. Perbandingan Peramalan Harga Beras Menggunakan Metode ARIMA pada Amazon Forecast dan Sagemaker. Jurnal Resti (Rekayasa Sistem dan Teknologi Informasi), 4(3), hal.537-543.

Marzuki, F., 2020. Banjir Susulan Rendam 40 Desa di 10 Kecamatan di Kebumen. https://rri.co.id/purwokerto/berita/kebumen/9 20205/banjir-susulan-rendam-40-desa-di-10kecamatan-di-kebumen. Diakses tanggal 13 Juli 2021.

Putra, D., 2010. Pengolahan Citra Digital, Yogyakarta: ANDI. Hal.95.

PUSDATARU JATENG (Pusat Data Tata Ruang Provinsi Jawa Tengah), 2018. Profil Wilayah Kebumen.

http://tataruang.pusdataru.jatengprov.go.id/pr ofil/detail_profil_kab_kota/296. Diakses 13 Juli 2021.

Pusat Informasi Perubahan Iklim, Kedeputian Klimatologi, 2020. Tanya Jawab: La Nina, El Nino dan Musim di Indonesia. Badan Meteorologi, Klimatologi, dan Geofisika.

Siswanto, Swarinoto, Y.S., Mas'at, A., 1999. The Interrelation between Atmospheric Circulation and Rainfall Amount in Jakarta and Surrounding Areas during La Nina Episode (a Case Study of December 1998). Bulletin Meteorology and Geophysics, 4, hal.8-14.

Subakti, H., 2012, Fluidized Bed Drying, in Mujumdar, A.S. (Ed.). Penuntun Praktikum Meteorologi, Universitas Sriwijaya, Palembang, pp. 3-12.

Sugiyono, 2014. Metode Penelitian Kuantitatif Kualitatif dan $R \& D$. Bandung. Alfabeta, 2014.

Supari, Tangang F, Salimun E, Aldrian E, Sopaheluwakan A, Juneng L. 2018. ENSO modulation of seasonal rainfall and extremes in Indonesia. Climate Dynamics. 51(7- 
8):2559-2580 . doi:10.1007/s00382-0174028-8.

Susila, Ida Bagus Kade P., Putra, I Dewa Nyoman N., Buana, Putu W., 2017. Rancang Bangun Aplikasi Analisa Pola Hujan Penyebab Banjir di Jakarta. Jurnal Merpati (Menara Penelitian Akademika Teknologi Informasi), 5(3), hal.151-161.

DOI: doi.org/10.24843/JIM.2017.v05.i03.p01

Swarinoto, Y. dan Sugiyono, 2011. Pemanfaatan Suhu Udara dan Kelembapan Udara dalam Persamaan Regresi untuk Simulasi Prediksi Total Hujan Bulanan di Bandar Lampung. Jurnal Meteorologi Geofisika, 12(3), hal.269279. 